\title{
Overview of the Facility Safeguardability Analysis (FSA) Process
}

RA Bari J Hockert EF Wonder
SJ Johnson

$\mathrm{R}$ Wigeland

MD Zentner

August 2012

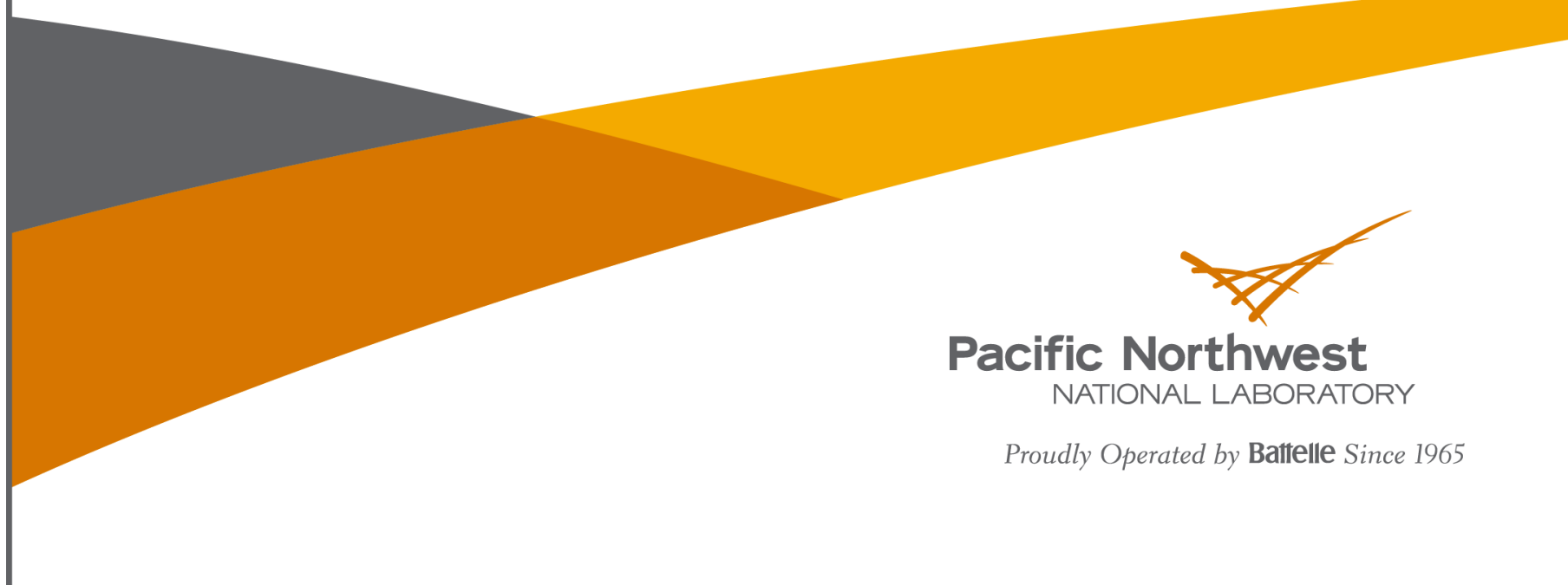




\title{
DISCLAIMER
}

This report was prepared as an account of work sponsored by an agency of the United States Government. Neither the United States Government nor any agency thereof, nor Battelle Memorial Institute, nor any of their employees, makes any warranty, express or implied, or assumes any legal liability or responsibility for the accuracy, completeness, or usefulness of any information, apparatus, product, or process disclosed, or represents that its use would not infringe privately owned rights. Reference herein to any specific commercial product, process, or service by trade name, trademark, manufacturer, or otherwise does not necessarily constitute or imply its endorsement, recommendation, or favoring by the United States Government or any agency thereof, or Battelle Memorial Institute. The views and opinions of authors expressed herein do not necessarily state or reflect those of the United States Government or any agency thereof.

\author{
PACIFIC NORTHWEST NATIONAL LABORATORY \\ operated by \\ BATTELLE \\ for the \\ UNITED STATES DEPARTMENT OF ENERGY \\ under Contract DE-AC05-76RL01830
}

Printed in the United States of America
Available to DOE and DOE contractors from the Office of Scientific and Technical Information,
P.O. Box 62, Oak Ridge, TN 37831-0062;
ph: (865) 576-8401
fax: $(865) 576-5728$
email: reports@adonis.osti.gov
Available to the public from the National Technical Information Service 5301 Shawnee Rd., Alexandria, VA 22312 ph: (800) 553-NTIS (6847)
email: orders@ntis.gov <http://www.ntis.gov/about/form.aspx>
Online ordering: http://www.ntis.gov

This document was printed on recycled paper. 
PNNL- 21698

\title{
Overview of the Facility Safeguardability Analysis (FSA) Process
}

\author{
RA Bari ${ }^{1}$ \\ SJ Johnson ${ }^{2}$ \\ $\mathrm{J} \mathrm{Hockert}^{3}$ \\ R Wigeland ${ }^{4}$ \\ EF Wonder ${ }^{5}$ \\ M.D. Zentner
}

October 2011

Prepared for the U.S. Department of Energy under Contract DE-AC05-76RL01830

\footnotetext{
${ }^{1}$ Brookhaven National Laboratory

${ }^{2}$ Tucker Creek Consulting

${ }^{3}$ XE Corporation

${ }^{4}$ Idaho National Laboratory

${ }^{5}$ QinetiQ North America
}

Pacific Northwest National Laboratory

Richland, Washington 99352 


\section{Executive Summary}

The safeguards system of the International Atomic Energy Agency (IAEA) is intended to provide the international community with credible assurance that a State is fulfilling its safeguards obligations. Effective and cost-efficient IAEA safeguards at the facility level are, and will remain, an important element of IAEA safeguards as those safeguards evolve towards a "State-Level approach." The Safeguards by Design (SBD) concept can facilitate the implementation of these effective and costefficient facility-level safeguards (Bjornard, et al. 2009a, 2009b; IAEA, 1998; Wonder \& Hockert, 2011). This report, sponsored by the National Nuclear Security Administration's Office of Nuclear Safeguards and Security, introduces a methodology intended to ensure that the diverse approaches to Safeguards by Design can be effectively integrated and consistently used to cost effectively enhance the application of international safeguards.

The Facility Safeguardability Assessment (FSA) methodology introduced here supports SBD in three areas:

1. It supports effective operator/designer engagement in the necessary interactions between the IAEA, the State regulator, and the owner/designer of a new or modified facility at the stages where the designer's SBD efforts can be applied most productively.

2. It presents a screening tool intended to help the designer identify potential safeguard issues for a) design changes to existing facilities, b) new facilities similar to existing facilities with established IAEA safeguards approaches, and c) new designs.

3. It provides a structured framework for the application of the SBD tools such as SBD good practice guides, design guidance, and safeguardability evaluation methods (called here the FSA toolkit). This toolkit can be used by the owner/designer to both identify potential safeguards issues and to develop solutions for potential safeguards issues during the interactions with the State regulator and IAEA.

The majority of new facilities are expected to reflect modest design evolution from existing safeguarded facilities. Therefore, a major focus of the FSA process is efficiently assessing the impact of such an evolution in facility or process design upon required safeguards-related design features. The more a design evolves or differs from the design of similar-type facilities, the greater the probability that new safeguards issues will be introduced, and the more challenging SBD becomes. FSA can help the designer anticipate where new safeguards challenges are posed, and the size of the gap between established safeguards approaches and safeguards tools and measures at existing facilities of the same type and what the IAEA might require for the new design. For first-of-a-kind facilities or research facilities that involve previously unused processes or technologies, comparison with previously required safeguard design features may not be sufficient. Accordingly, a comprehensive vulnerability or path assessment may be required to adequately identify and assess new safeguards issues.

Designers/owners of nuclear facilities subject to IAEA safeguards can employ FSA to identify potential safeguards issues early in the design process and incorporate, in a cost-effective manner, design 
measures that will facilitate effective implementation of IAEA safeguards. As this report demonstrates, the FSA can help the designer and its safeguards experts identify or anticipate:

- Areas where elements of previous established safeguards approach(es) may be applied to facility modifications or new designs

- Modifications of the facility design that could mitigate a potential safeguards issue or facilitate a more efficient application of the safeguards approach

- Possible innovative ideas for more efficient application of IAEA safeguards tools and measures

- The potential for changes in elements of the safeguard approach that may be required by the IAEA as a result of facility design features and characteristics.

FSA should help ensure that the facility design is compatible with the needs of the safeguards approach of the State and the IAEA. A key element of SBD is early and iterative interaction among the designer/operator, Safeguards Regulatory Authority (SRA)/Regional Safeguards Regulatory Authority (RSRA), and the IAEA. 



\section{Acronyms and Abbreviations}

$\begin{array}{ll}\text { CoK } & \text { Continuity of Knowledge } \\ \text { DIE } & \text { Design Information Examination } \\ \text { DIV } & \text { Design Information Verification } \\ \text { EEL } & \text { Essential Equipment List } \\ \text { FKMP } & \text { Flow Key Measurement Points } \\ \text { FSA } & \text { Facility Safeguardability Assessment } \\ \text { IAEA } & \text { International Atomic Energy Agency } \\ \text { IIV } & \text { Interim Inventory Verification } \\ \text { IKMP } & \text { Inventory Key Measurement Points } \\ \text { KMP } & \text { Key Measurement Points } \\ \text { LEU } & \text { low enriched uranium } \\ \text { LOF } & \text { locations outside facilities } \\ \text { MBA } & \text { Material Balance Area } \\ \text { MOX } & \text { mixed oxide } \\ \text { OSP } & \text { Other Strategic Points } \\ \text { PIL } & \text { Physical Inventory List } \\ \text { PIT } & \text { Physical Inventory Taking } \\ \text { PIV } & \text { Physical Inventory Verification } \\ \text { SBD } & \text { Safeguards by Design } \\ \text { SGER } & \text { Safeguards Effectiveness Report } \\ \text { SRA } & \text { State Regulatory Authority } \\ \end{array}$





\section{Contents}

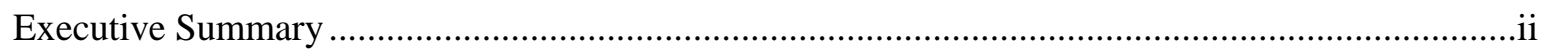

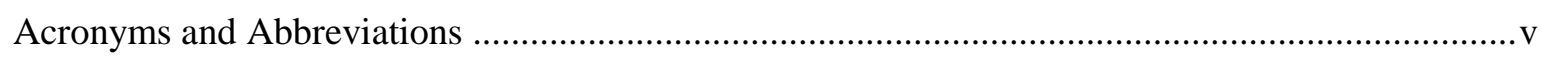

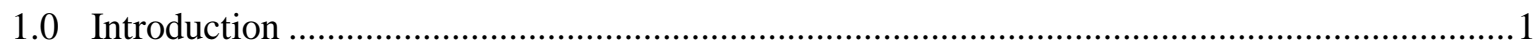

2.0 Designer Interaction with State Regulator and IAEA .....................................................

2.1 Provision of Design Information to IAEA ................................................................

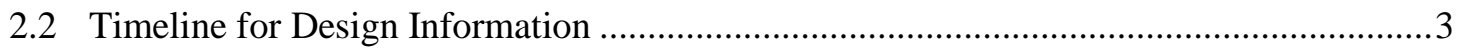

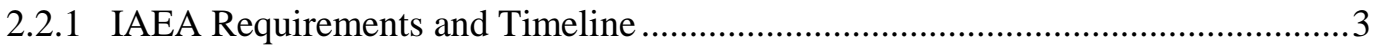

2.3 Communication of IAEA Requirements and Facility Design .....................................6

2.3.1 Establishment of the Facility Safeguards Approach ...........................................6

2.3.2 Establishment of the Essential Equipment List .................................................

2.3.3 Preparation of the Facility Attachment ............................................................

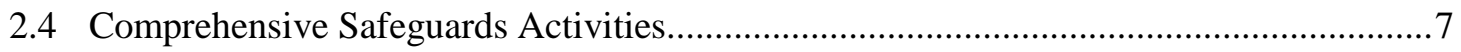

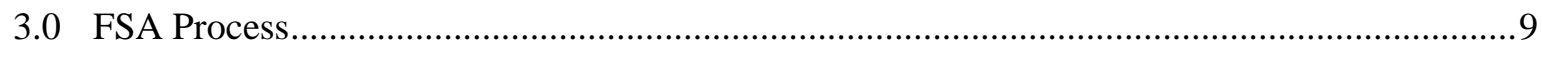

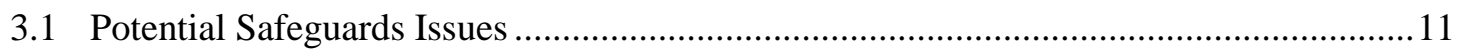

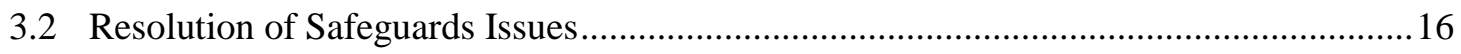

4.0 Facility Safeguardability Analysis Toolbox …............................................................... 17

4.1 SBD Good Practices Guides Developed by the United States ........................................17

4.1.1 Safeguards by Design General Guidance .......................................................... 18

4.1.2 Safeguards Guidance Documents for Nuclear Reactors .....................................18

4.1.3 Safeguards Guidance Documents for Processing and Storage Facilities ...............18

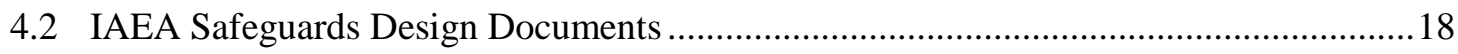

4.3 Lessons-learned Reports .................................................................................... 19

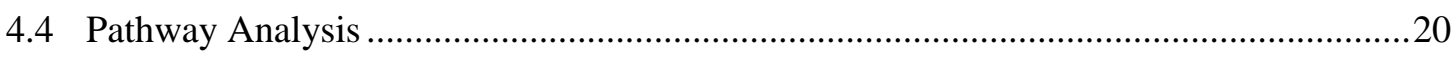

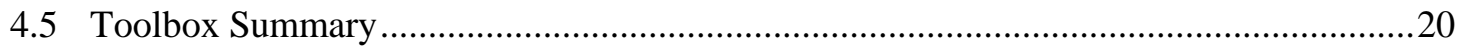

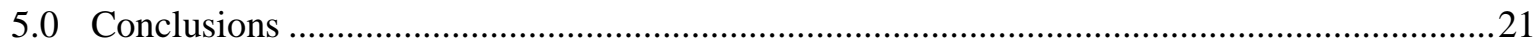

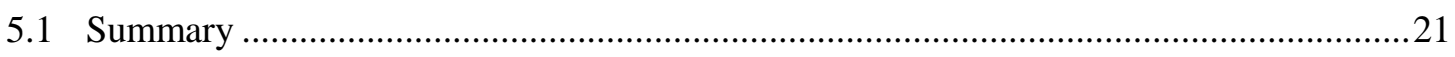

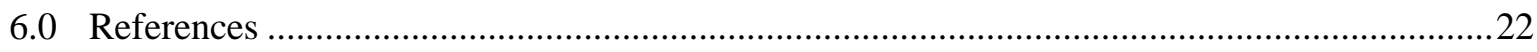




\section{Figures}

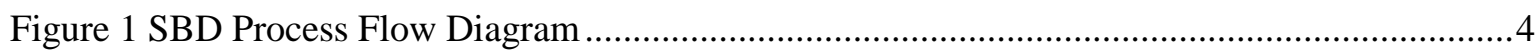

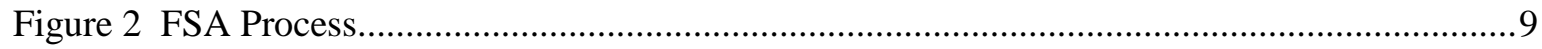

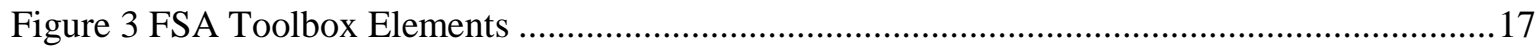

\section{Tables}

Table 1 Facility Safeguardability Assessment Screening Questions .............................................13

Table 2 Effect of Design Differences on Physical Inventory Verification ...................................... 14

Table 3 Effect of Design Differences on Interim Inventory Verifications .................................... 14

Table 4 Effect of Design Differences on Inventory Change Measurement .................................... 15

Table 5 Effect of Design Differences on Other Strategic Points ................................................. 16 
PNNL-21698

\subsection{Introduction}

The safeguards system of the International Atomic Energy Agency (IAEA) is intended to provide the international community with credible assurance that a State is fulfilling its safeguards obligations. Efficiency and effectiveness are important elements of IAEA safeguards. Safeguards by Design (SBD) can contribute to such effective and cost-efficient facility-level safeguards.

SBD is the process of incorporating features to support international safeguards into nuclear facility designs starting in its conceptual design phase. It is intended to be an element of the design process for a new nuclear facility from initial planning through design, construction, operation, and decommissioning. The SBD process includes use of design measures that make the implementation of safeguards at such facilities more effective and efficient (i.e., so that the facility misuse and/or diversion of nuclear material can be readily and reliably detected and to minimize the impact of safeguards on the operator to the extent possible).

This report presents a "Facility Safeguardability Analysis" (FSA) process that designers can use to identify potential safeguards issues early in the design process and incorporate, in a cost-effective manner, design measures that will facilitate effective and efficient implementation of IAEA safeguards. While it can be utilized throughout the complete design process, FSA is intended to be initially applicable during the conceptual design stage, when many of the design decisions crucial to facility cost and schedule are made and when the Safeguards Regulatory Authority (SRA) and the IAEA can be engaged early on to resolve safeguards issues with minimal cost and schedule impact.

A qualitative measure of SBD, referred to as safeguardability, is defined as "the degree of ease with which a nuclear energy system can be effectively and efficiently placed under international safeguards." (GIF/PRPPWG, 2011) While any nuclear energy system can be safeguarded given sufficient resources, the goal of these assessments is to evaluate the degree of ease with which IAEA technical objectives can be met in a cost effective fashion and to establish facilities whose process, design, and layout support the effective and efficient implementation of IAEA safeguards.

Section 2.0 of the report describes the IAEA requirements and the information that the IAEA currently requires from designers including early design information for new facilities (IAEA, 1972). These requirements provide a basis for the early initiation of SBD activities, and by extension, for analyzing the safeguardability of the proposed design for the facility. Section 2 presents the Life Cycle Phase assigned by IAEA to all nuclear facilities, and the associated set of significant activities undertaken during the various stages of designing and building a new facility. Section 2 also addresses how IAEA requirements are communicated and the importance of early design considerations and the associated impact on the implementation of safeguards and related "deliverables" to the IAEA.

Section 3.0 describes the general FSA process that the designer can use to begin the implementation of SBD by identifying areas where changes/innovations introduced in a new design or applied to operating facilities are likely to create new safeguards issues. Section 4.0 summarizes the elements of the "toolbox" of facility-type specific SBD best practices. Conclusions and recommendations are presented in Section 5.0. 



\subsection{Designer Interaction with State Regulator and IAEA}

\subsection{Provision of Design Information to IAEA}

The SRA is responsible for notifying the IAEA of the planned construction of a new nuclear facility when the decision to build is approved. As discussed below, the SRA provides progressively more detailed information to the IAEA as the project moves through the design and construction stages. The responsibility for providing the information to the SRA to meet the requirements of the applicable international safeguards agreement and for facilitating IAEA inspector access to the facility falls upon the facility owner/operator. The owner/operator interactions are with the SRA who interacts with the IAEA. The owner /operator also manages the facility designers, constructors, and equipment suppliers. Figure 1 demonstrates the interactions among the designer, owner/operator, SRA, and IAEA.

The owner/operator of the facility is the entity responsible for developing the design information supplied to the IAEA and ultimately will support the IAEA implementation of safeguards and host inspections during construction and operation. However, in SBD the facility designer will play a key role in ensuring that the facility design facilitates IAEA safeguards implementation to the extent possible. Whether the "designer" is part of the same industrial entity as the operator or is a separate company (e.g., a vendor), the owner/operator is responsible for providing the designer with all national and international requirements. The owner/operator works with the State to ensure that all safeguards considerations are met. Initiating SBD early in the facility design process by working with the SRA and the IAEA is the responsibility of the owner / operator or his design / construction manager.

In some instances a vendor may develop standardized facility designs for use in multiple locations. Under these circumstances, the initial IAEA review will be based on the facility type, its architectural and process-related characteristics, and will not depend on the final siting of the facility. When a user is identified, then the process described below regarding provision of design information to the IAEA will be followed. At this point, the IAEA will be able to take State-specific factors into account in developing its safeguards approach.

\subsection{Timeline for Design Information}

\subsubsection{IAEA Requirements and Timeline}

The basis for all IAEA activities concerning design information examination and verification is found in Articles 8, 42-48 and 83(a) of INFCIRC/153 ( IAEA, 2009). Additionally, the model Subsidiary Arrangements for comprehensive safeguards agreements calls for the provision of a completed IAEA Design Information Questionnaire (DIQ) for a new facility not later than 180 days before the facility is scheduled to receive nuclear material for the first time. The Board of Governors reaffirmed and strengthened the rights and need for examination and verification of design information in Board of Governors Documents (IAEA, 1992; IAEA, 1996). 


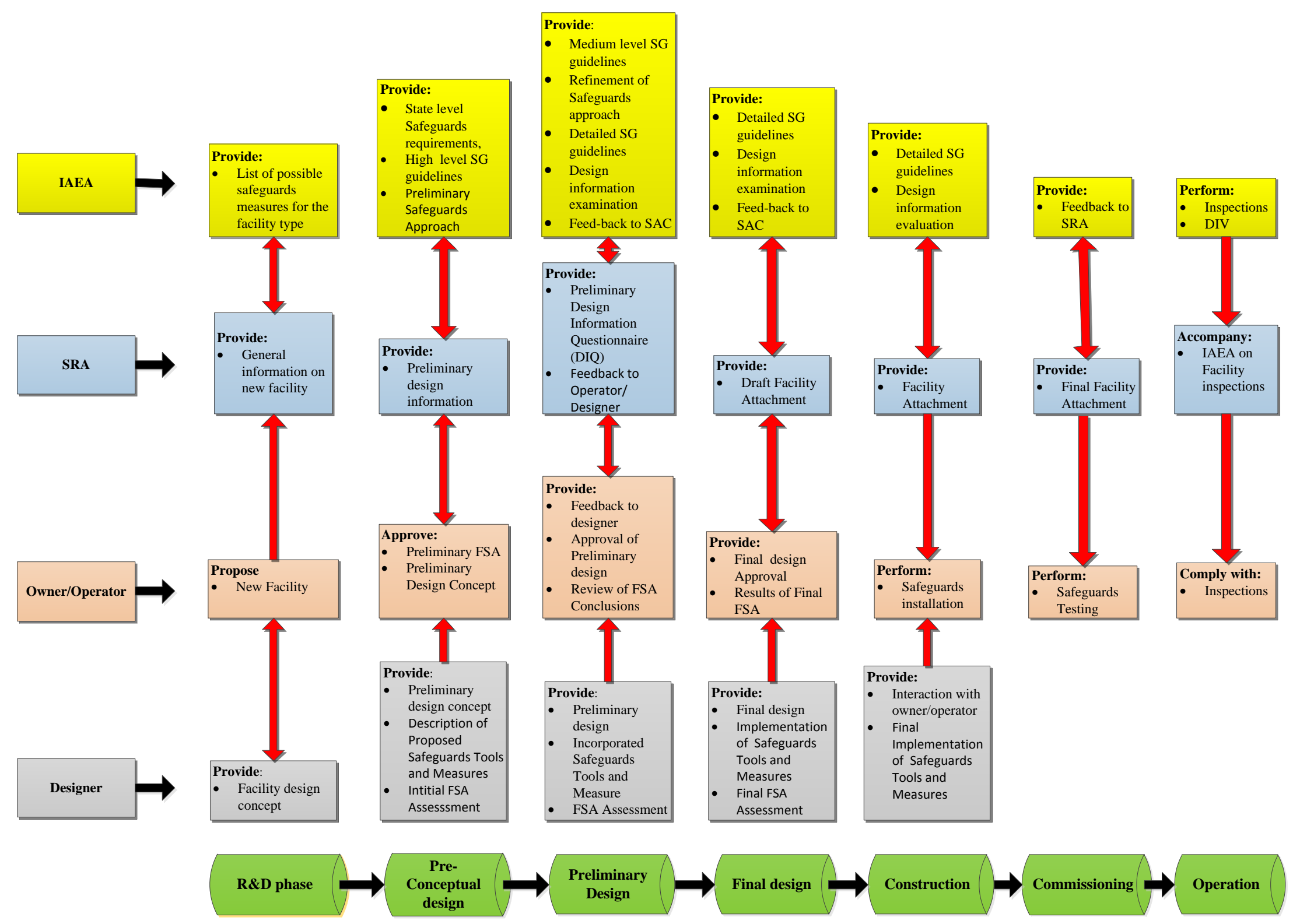

Figure 1 SBD Process Flow Diagram 
At the time of the decision to construct, or to authorize the construction of any nuclear facility, the SRA should provide information to the IAEA that will:

- Facilitate the incorporation into the facility design - including the design of the nuclear materials accountancy system - features which will make it easier to implement safeguards at the facility

- Allow time for safeguards research and development work that may be necessary

- Enable the Agency to do the budgetary planning necessary for the effective and efficient implementation of safeguards,

- Permit the identification and scheduling of actions which need to be taken jointly by the State, the facility operator and the Agency, including

$\bigcirc$ installation of safeguards equipment during construction of the facility,

- verification of information on the design of the facility.

In order to ensure that the early provision of design information on new or modified facilities is adequate and meets IAEA requirements, the SRA should:

- Inform the IAEA of new nuclear facilities and activities and any modifications to existing facilities via the provision of preliminary design information as soon as the decision to construct, to authorize construction or to modify has been taken;

- Provide the IAEA with further information on designs as they are developed. The information should be provided early in the project definition, preliminary design, construction and commissioning phases;

- Provide the Agency with Design Information for new facilities based on preliminary construction plans as early as possible, to facilitate Design Information Examination and Verification by IAEA as the facility as built. . A Final Design Information Questionnaire based on "as-built" designs should be provided as early as possible, and in any event not later than 180 days before the first receipt of nuclear material at the facility.

The IAEA assigns a Life Cycle Phase to all facilities (or parts of a facility). The required design information and associated Design Information Examination (DIE) and Design Information Verification (DIV) activities are determined by the Life Cycle Phase and the type of facility. These phases are primarily determined by the facility's operating capabilities. These Life Cycles Phases are (Johnson, 2009);

- Pre-Construction Phase -
○ $R \& D$ Phase
○ Pre-conceptual Design
- Preliminary Design
- Final Design

- Construction Phase 
- Commissioning Phase

- Operating Phase

- Maintenance or Modification Phase

- Shutdown Phase

- Closed-Down Phase

- In a State of Preservation

- In a State of Decommissioning

- Decommissioned for Safeguards Purposes.

The early phases are critical times for close IAEA, State, and designer/operator interactions concerning safeguards and design requirements. The decisions made during the early phases will have a large impact on the implementation of safeguards during later Life Cycle Phases. Decisions delayed to later phases could negatively impact cost and facility start up.

The designer's analysis of the safeguardability of the design should be completed by the end of the IAEA-defined Pre-Construction Phase, to ensure that any safeguards issues/challenges associated with the design are discussed up front with the SRA and IAEA. Continuing IAEA DIV activities would be conducted where needed during the construction and cold commissioning phases to ensure that 1) any design modifications made during construction do not negatively impact safeguards, and 2) that the design as-built will support safeguards implementation as anticipated during the Pre-Construction Phase.

\subsection{Communication of IAEA Requirements and Facility Design}

The State generally establishes requirements mandating that the owner/operator supply design information to the SRA who then reviews and approves the information before transmitting it to the IAEA. The IAEA uses this information to 1) develop the safeguards approach, 2) establish the Essential Equipment List (EEL) and 3) prepare the Facility Attachment.

\subsubsection{Establishment of the Facility Safeguards Approach}

The IAEA is responsible for establishing a safeguards approach (SA) for a facility. The safeguards approach is a set of safeguards measures established for the implementation of safeguards in a given situation. It will define the means for the facility to meet applicable safeguards objectives and may identify recommendations for safeguards measures that will help improve efficiency while enabling the IAEA to meet its goals. The SA is based on the following:

- Determination of possible diversion strategies, pathways and possible concealment actions,

- Determination of potential misuse of the facility

- Determination of the appropriate safeguards measures required to meet the IAEA Safeguards Goals

- Results of the design information examination and verification. 
The IAEA does not use a set structure or format for the preparation and documentation of the safeguards approach. This is primarily because the inspection activities, the inspection effort, and the equipment requirements vary widely depending on the facility size, location, complexity, and type.

\subsubsection{Establishment of the Essential Equipment List}

The EEL, first established by the IAEA during the initial DIE and DIV activities, is a list of facility specific equipment, systems and structures essential for the declared operation of a facility. The EEL is established according to each facility's function, capability, and safeguards approach, and is re-examined annually by the IAEA and updated as required. It should identify equipment that may influence the facility's operational status, function, capabilities and inventory and/or throughput. The operator is obligated to notify the IAEA through the SRA of planned changes to the facility that might impact the safeguards approach. The following criteria are used in establishing the EEL (Cooper, et al., 2002).:

- The essential nature of the equipment, system or structure to the facility's function

- The commercial availability

- The complexity of modification, re-installation or repair

- The time required for modification, re-installation or repair

- The potential for detection of modification, re-installation or repair.

\subsubsection{Preparation of the Facility Attachment}

The preparation of the Facility Attachment (FA) for a specific facility is initiated by the IAEA and negotiated with the SRA. The facility owner/operator provides significant technical support to the State in these negotiations. The details of the interaction between the SRA and the facility owner/operator depend upon the nature of the SRA, which is often a regulatory agency responsible for interacting with the facility owner/operator. In states with strong and well-established SRAs, or those under regional SRAs such as EURATOM and ABACC, there may also be domestic or regional safeguards requirements imposed upon the facility owner/operator in addition to those of the IAEA.

The structure of the FA is based on a model attachment and should reflect the specific arrangements made with the State for the implementation of safeguards at the facility. These arrangements should be based on the design information provided by designer and operator, the safeguards approach, inspection goals and procedures, and other relevant facility information.

\subsection{Comprehensive Safeguards Activities}

Under a comprehensive safeguards agreement, four major areas of operator and inspector activities must be considered by the designer when incorporating safeguardability into a facility:

1. A Physical Inventory Taking (PIT) is conducted by the operator in order to prepare a Physical Inventory List (PIL). The inspectors then carry out a Physical Inventory Verification (PIV) of the declared inventory. At the time of a PIT/PIV, all nuclear material must be in locations where it can 
be measured. These locations are defined as Inventory Key Measurement Points (IKMP), which must be designed to allow for an efficient PIT by the operator and an effective PIV by the inspectors.

2. An interim inventory declaration is prepared by the operator for a selected cut-off time. The inspectors then carry out an Interim Inventory Verification (IIV) to meet the timeliness goal for specific nuclear material (depending on the type of nuclear material and its form, these goals vary from 1 month to 1 year). At the time of the IIV all nuclear material must be in locations that can either be measured, determined by indirect means, or have been measured previously with continuity of knowledge (CoK) being maintained. These locations may be more expansive than those at the time of a PIT/PIV, especially in flow processes. The interim inventory locations must be included when defining the IKMPs, and the need for timely and accurate measurement capabilities for both the operator and inspector must be considered in the design. A PIV does satisfy the goals for the IIV when they coincide (therefore a facility is not subjected to a separate IIV and PIV at the same time).

3. As nuclear material is transferred across Material Balance Area (MBA) boundaries, the operator declares the inventory increases and decreases in an Inventory Change Report. The inspectors verify the ICs according to the Safeguards Approach. The measurement points at the MBA boundaries are defined as Flow Key Measurement Points (FKMP) and must be designed to allow for timely and accurate declarations by the operator and verification by the inspectors.

4. Within the MBAs, Other Strategic Points (OSP) may be identified. The OSPs, which are not accountancy points, may be required to provide added assurance to accountancy measurements with high uncertainties, to maintain CoK of verifications done at KMPs, or to confirm that operations of the facility are as declared. OSPs may include such activities as containment and/or surveillance, verification of flows within an MBA, monitoring of process flows, or short-notice visit to selected locations in the facility. To assure adequate access and measurement capabilities, OSPs need to be defined early in the design by interactions between the principals involved (i.e., SRA, IAEA, Designer, Operator) 


\subsection{FSA Process}

The FSA process, shown in Figure 2, is designed to cost-effectively identify differences between a proposed facility design and the design of a similar facility with an established IAEA safeguard approach. The process identifies potential changes in safeguards tools and measures needed to accommodate the new design. This process could also be used to evaluate the effect of facility design modifications on an existing safeguards approach. Since new facility designs usually incorporate proven design concepts and features from existing facilities for which IAEA safeguards approaches have been developed, ${ }^{1}$ it is likely that aspects of the safeguards tools and measures used for new facilities will be similar to those of current facilities.

If the operator is building or modifying a standardized facility design for which a well-understood safeguards approach already exists and is accommodated in the standardized design, the effort to analyze its safeguardability may be very modest. However, consideration should be given to the fact that many existing safeguards tools and measures could be made more efficient with slight modifications to the "standardized" facility design or operating procedures, and this should be considered in a FSA.

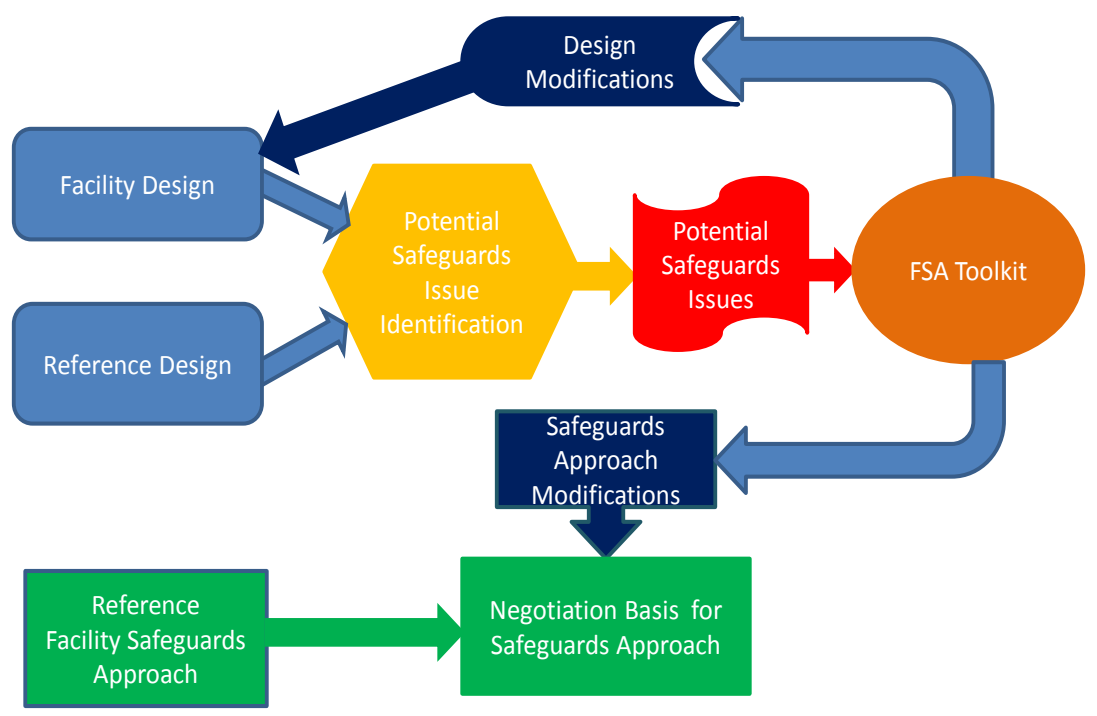

\section{FSA Process}

Figure 2 FSA Process

A greater effort to ensure facility safeguardability will be needed for new facilities that include novel design features or present particular safeguards challenges, such as large bulk processing facilities.

\footnotetext{
${ }^{1}$ First-of-a-kind and research facilities are expected to present a wider range of new safeguards challenges, in part because precedents from safeguards approaches for deployed commercial facilities may not be applicable or appropriate. For commercially deployed facilities, we would expect designers to employ engineering conservatism, such that they employ design elements in which they and their customers have high degrees of confidence. In this latter case, safeguards precedents are likely to be very instructive.
} 
Accordingly, a process for analyzing the safeguardability of a facility design should be readily scalable to match the relative safeguards challenges.

The safeguards subject matter experts on the design team should have experience with the safeguards tools and measures used in similar, currently deployed facilities and should be familiar with existing safeguards approaches. When implementing SBD using the FSA process, the design team's first task is to identify potential changes in IAEA safeguards approaches that may be needed or individual safeguards tools and measures caused by differences in the design of the new or modified facility or the availability of new safeguards technologies. Once these have been identified, the designer could:

- Modify the new design to eliminate the potential need for a change in safeguards approach

- Call attention to the differences and the potential safeguards issues in discussions with the SRA and the IAEA. These discussions would be focused on any required changes to the safeguards tools and measures to be used and any design modifications needed to support the revised safeguards approach (see Figure 1).

Once the broad outlines of the safeguards approach for the new facility are communicated by the SRA and IAEA, the design features needed to support that approach can be included in the design. The objective of the FSA process is to assist the owner/operator/designer in understanding the potential impact of:

- Departing from "comparison" facility designs ${ }^{2}$

- Changes as the design matures

- Design modifications made in response to SRA and IAEA safeguards concerns that are intended to ensure that adequate domestic and international safeguards are provided in the facility.

Use of FSA process will enable the owner/operator/designer to draw the attention of the SRA and IAEA to design changes and features that may have potential IAEA safeguards impact early in the design process. At this stage, it is relatively easy and inexpensive to include design features to support or implement the new approach. It is important to note that the FSA process may also identify intrinsic improvements in facility safeguardability as a result of design improvements that may result in more efficient and cost effective safeguards tools and measures.

As the design evolves, the FSA process permits the owner/operator/designer to manage elements that will affect established safeguards tools and measures. Should it be desirable to make changes to aspects of the design, the FSA process enables the owner/operator/designer to make a preliminary assessment of the impact of the proposed changes on the safeguardability of the facility. This process supports the owner/operator/designer's systems engineering review and acceptance of the proposed design change along with identification of "potential safeguards issues".

If the decision is made to implement the proposed design change, the FSA process should help identify applicable information for the owner/operator/designer to provide to the SRA and IAEA so that the required safeguards approach can be modified by IAEA earlier in the design process than would have

\footnotetext{
${ }^{2}$ Various sources of facility designs can be used as comparison facilities. For example, in many cases the facility owner/designer will have experience with the design, construction, and safeguarding of similar facilities that is directly applicable. The IAEA also may choose to provide model safeguards approaches for general facility types that can be tailored using FSA.
} 
otherwise been practicable. The FSA process also provides information that may help the owner/operator/designer identify alternate safeguards tools and measures and lessen the impact of required changes on facility design, construction costs and schedule, and subsequent operational costs. It should be clearly understood in this context that the operator/designer works with the SRA, which in turn engages with the IAEA, and that the IAEA is the final arbiter of what safeguards approach it will employ and the tools and measures it will use to implement that approach.

\subsection{Potential Safeguards Issues}

The FSA process employs a screening tool (Summarized in Table 1) to identify aspects of the new design that may create potential safeguards issues when compared to similar existing facilities for which the IAEA has implemented a safeguards approach.

This screening tool can be used early in the design process by the designer and its safeguards experts to evaluate the safeguardability of new designs or modifications. Proposed design changes can be formally reviewed using the screening tool to identify potential safeguards issues if implemented. This permits configuration control for facility safeguardability in a manner analogous to configuration management for facility safety. In addition, this screening approach helps ensure that the need for addressing potential safeguards issues is identified during the consideration of the changes that give rise to them.

Importantly, if the design of a new facility deviates in significant measure from that of predecessor facilities, even if those facilities are of the same type and use the same technology, there may be a potential for new or previously unexamined safeguards issues posed by the new design. Additionally, because of advances in safeguards tools and measures, it may be appropriate to reevaluate previous safeguards tools and measures used in older facilities to determine if they are appropriate for efficient use in new facilities.

When using this screening tool, it is important to remember that the questions are based upon comparison of the new design with a comparison facility design. As the screening tool indicates, potential safeguards issues can arise in four fundamental ways. Design differences can:

1. Create additional or alter existing diversion paths, undermining confidence that the safeguards approach is capable of detecting covert removal of nuclear material;

2. Increase the difficulty of design information examination and verification, decreasing the IAEA's assurance that established inspection activities will provide sufficient information to verify that there has been no indication of diversion of declared nuclear material and no indication of undeclared nuclear material or activities in the State;

3. Impede the IAEA's capability to verify that diversion has not taken place (i.e., all nuclear material is in declared areas); and/or

4. Create a new or alter an existing potential for the facility to be misused for undeclared activities or make the detection of such misuse more difficult. 
Under these circumstances, the IAEA is likely to require changes in the safeguards tools and measures that were used at the comparison facility to ensure its ability to achieve its safeguards technical objectives at the facility. ${ }^{3}$ Alternatively, the FSA may determine that because of facility design evolution and improvements in process layout, it may be easier or more cost effective to apply modern safeguards tools and measures to the new design.

These four issues are addressed by the four top-level questions in Table 1. The lower-level questions in Table 1 highlight design or process differences that can create potential safeguards issues. Tables 2 through 5 provide details needed to answer questions 3.1-3.4.

Question 1.0 highlights the possible presence of different types, categories, or forms of nuclear material that may require new safeguards tools to detect diversion of different significant quantities within different detection times (as defined in the IAEA safeguards technical objectives). Questions 1.2 and 1.3 highlight changes in physical barriers or layout that would reduce the effectiveness of containment/surveillance safeguards, impede the installation of verification measurement and monitoring systems, or create or modify physical removal paths. Finally, Question 1.4 addresses the introduction of new materials that could potentially be employed to circumvent safeguards measures designed to detect diversion (e.g., inert materials or items that could be covertly substituted for spent fuel pins in feed material at a reprocessing plant).

Question 2.0 addresses design information examination and verification. Screening tool question 2.1 focuses on the potential incorporation of new facility design or process technologies that may pose unique or different design evaluation, verification, or general safeguards challenges. Question 2.2 focuses on technology or process sensitivities that could limit IAEA access to information about equipment or to the equipment itself. This potentially could limit the IAEA's ability to evaluate the equipment for potential safeguards vulnerabilities or to verify that it has been installed and operated as declared by the facility. Question 2.3 addresses other aspects of the design that might impede inspector access to essential equipment to verify that it has been installed and operated as declared by the facility. Question 2.4 focuses on aspects of the design that might be used to conceal modifications to the design or operation of the plant, or prevent continuous design verification throughout the lifetime of the plant.

Question 3.0 addresses design differences that might make it difficult for the IAEA to verify that no diversion ${ }^{4}$ has taken place. Questions 3.1-3.4 are further developed in the Tables that follow.

Question 4.0 of Table 1 addresses design differences that might increase the potential for facility misuse or make misuse more difficult to detect. Question 4.1 highlights differences in the design or process steps or equipment that may make it possible to change the type, category, or form of the nuclear material particularly if it results in a different significant quantity or detection time for diversion.

Questions 4.2 and 4.3 address design differences that would make facility misuse more difficult to detect,

\footnotetext{
${ }^{3}$ Although the screening questions focus on identifying areas where the new design makes safeguarding more difficult, features of the new design that facilitate safeguarding should also be noted. These features may make a significant contribution to the efficient, cost-effective resolution of potential safeguards issues.

${ }^{4}$ Diversion is the process of surreptitiously removing safeguarded material from a facility. Misuse involves the use of material, services, or equipment in the facility to change material so that it is weapons usable or to create new material that is weapons usable.
} 
by compromising the effectiveness of short-notice visits should they be called for in the safeguards approach or by reducing the transparency of the facility operations.

Table 1 Facility Safeguardability Assessment Screening Questions

\begin{tabular}{|c|c|c|}
\hline \multicolumn{3}{|c|}{ Facility Safeguardability Assessment Screening Questions } \\
\hline 1. & $\begin{array}{l}\text { Does this design differ from the comparison design / process in ways that have the potential to create } \\
\text { additional diversion paths or alter existing diversion paths? }\end{array}$ & Yes / No \\
\hline & $\begin{array}{l}\text { 1.1. Does this design introduce nuclear material of a type, category, or form that may have a different } \\
\text { significant quantity or detection time objective than previous designs/processes (e.g., mixed oxide } \\
\text { rather than low enriched uranium, irradiated vs. unirradiated or bulk rather than items)? }\end{array}$ & Yes / No \\
\hline & $\begin{array}{l}\text { 1.2. Does this design layout eliminate or modify physical barriers that would prevent the removal of } \\
\text { nuclear material from process or material balance areas, e.g., circumventing a key measurement } \\
\text { point (KMP)? }\end{array}$ & Yes / No \\
\hline & $\begin{array}{l}\text { 1.3. Does this design obscure process areas or material balance area (MBA) boundaries making } \\
\text { containment/surveillance or installation of verification measurement and monitoring equipment } \\
\text { more difficult? }\end{array}$ & Yes / No \\
\hline & $\begin{array}{l}\text { 1.4. Does this design introduce materials that could be effectively substituted for safeguarded nuclear } \\
\text { material to conceal diversion? }\end{array}$ & Yes / No \\
\hline & $\begin{array}{l}\text { Does this design differ from the comparison design in a way that increases the difficulty of design } \\
\text { information examination (DIE) and verification (DIV) by IAEA inspectors? }\end{array}$ & Yes / No \\
\hline & $\begin{array}{l}\text { 2.1. Does the design incorporate new or modified technology? If so, does the IAEA have experience } \\
\text { with the new or modified technology? }\end{array}$ & Yes / No \\
\hline & $\begin{array}{l}\text { 2.2. Are there new design features with commercial or security sensitivities that would inhibit or } \\
\text { preclude IAEA inspector access to equipment or information? }\end{array}$ & Yes / No \\
\hline & $\begin{array}{l}\text { 2.3. Do aspects of the design limit or preclude inspector access to, or the continuous availability of, } \\
\text { Essential Equipment for verification or testing? }\end{array}$ & Yes / No \\
\hline & $\begin{array}{l}\text { 2.4. Are there aspects of the design that would preclude or limit IAEA maintenance of Continuity of } \\
\text { Knowledge }(\mathrm{CoK}) \text { associated with design verification during the life of the facility. }\end{array}$ & Yes / No \\
\hline & $\begin{array}{l}\text { Does this design/process differ from the comparison design / process in a way that makes it more } \\
\text { difficult to verify that diversion has not taken place? }\end{array}$ & Yes / No \\
\hline & $\begin{array}{l}\text { 3.1. Does this design lessen the efficiency of physical inventory taking (PIT) by the operator or the } \\
\text { effectiveness of physical inventory verification (PIV) by the IAEA? }\end{array}$ & Yes / No \\
\hline & $\begin{array}{l}\text { 3.2. Does this design impair the ability of the operator to produce timely and accurate interim } \\
\text { inventory declarations or for the IAEA to perform timely and accurate Interim Inventory } \\
\text { Verification (IIV)? }\end{array}$ & Yes / No \\
\hline & $\begin{array}{l}\text { 3.3. Does this design impede timely and accurate inventory change (IC) measurements and } \\
\text { declarations by the operator and verification by the IAEA? }\end{array}$ & Yes / No \\
\hline & $\begin{array}{l}\text { 3.4. Does this design impede the introduction of or reduce the usefulness of Other Strategic Points } \\
\text { (OSP) within a Material Balance Area (MBA)? }\end{array}$ & Yes / No \\
\hline & $\begin{array}{l}\text { Does this design differ from the comparison design in ways that create new or alter existing } \\
\text { opportunities for facility misuse or make detection of misuse more difficult? }\end{array}$ & Yes / No \\
\hline & $\begin{array}{l}\text { 4.1. Does this design differ from the comparison facility / process by including new equipment or } \\
\text { process steps that could change the nuclear material being processed to a type, category, or form } \\
\text { with a lower significant quantity or detection time objectives? }\end{array}$ & Yes / No \\
\hline & $\begin{array}{l}\text { 4.2. Should the comparison facility safeguards approach employ agreed upon short-notice visits or } \\
\text { inspections, measurements, or process parameter confirmations, would this design preclude the } \\
\text { use of or reduce the effectiveness of these measures? }\end{array}$ & Yes / No \\
\hline & $\begin{array}{l}\text { 4.3. Do the design and operating procedures reduce the transparency of plant operations (e.g., } \\
\text { availability of operating records and reports or source data for inspector examination or limited } \\
\text { inspector access to plant areas and equipment)? }\end{array}$ & Yes / No \\
\hline
\end{tabular}


The questions in Table 2 address design differences that would affect the efficiency or accuracy of the operator's physical inventory or the IAEA inventory verification. The physical inventory and IAEA inventory verification are key elements needed to establish and verify material balances capable of detecting diversion.

Table 2 Effect of Design Differences on Physical Inventory Verification

\begin{tabular}{|l|c|}
\hline 3.1. $\begin{array}{l}\text { Does this design lessen the efficiency of physical inventory taking (PIT) by the operator or } \\
\text { the effectiveness of physical inventory verification (PIV) by the IAEA? }\end{array}$ & Yes / No \\
\hline $\begin{array}{l}\text { 3.1.1. Does the plant/process design reduce the measurement accuracy or otherwise impede } \\
\text { the use of Inventory Key Measurement Points (IKMP). If so, are there other well } \\
\text { defined locations that could be considered by the IAEA as IKMPs. }\end{array}$ & Yes / No \\
3.1.2. Does the plant/process design impede or preclude the collection/storage of inventory \\
at IKMPs at the time of PIT/PIV? & Yes / No \\
\hline $\begin{array}{l}\text { 3.1.3. Does the design preclude PIT/PIV measurements on some inventory? If so, does the } \\
\text { new design include features to permit CoK to be maintained from a previous } \\
\text { measurement and verification? }\end{array}$ & Yes / No \\
$\begin{array}{l}\text { more difficult to measure accurately at IKMP? If so, can the plant accountancy } \\
\text { measurement systems meet International Target Values (ITV) for the PIT? }\end{array}$ & Yes / No \\
\hline $\begin{array}{l}\text { 3.1.5. Does the design preclude or limit the ability of the IAEA to take/analyze independent } \\
\text { samples for the PIV? }\end{array}$ & Yes / No \\
\hline $\begin{array}{l}\text { between the time of the PIT and the PIV? If so, does the design include measures to } \\
\text { maintain CoK of the changed or moved inventory between the time of the PIT and the } \\
\text { PIV? }\end{array}$ & Yes / No \\
\hline \begin{tabular}{l} 
3.1.6. Does the process design preclude controls to prevent inventory change or movement \\
\hline
\end{tabular}
\end{tabular}

The questions in Table 3 address design differences that would have a similar effect on the efficiency or accuracy of the operator's interim inventory declaration and the IAEA verification of the interim inventory for timeliness.

Table 3 Effect of Design Differences on Interim Inventory Verifications 
3.2. Does this design impair the ability of the operator to produce timely and accurate interim inventory declarations and for the IAEA to perform timely and accurate Interim Inventory Verification (IIV) for timeliness?

3.2.1. Does design impede or preclude shutdown of the process for an IIV?

3.2.2. Does the design impede or preclude the collection/storage of inventories at IKMP, which provide access for measurement and declaration by the operator and verification by the IAEA, at the interim inventory cut-off time (CoT)?

3.2.3. Does design create the potential for Un-Measureable Inventory (UMI) at the time of an IIV in locations such as pipes, pumps, or evaporators? If so, can the UMI be accurately estimated by the operator and can the estimation method be verified by the IAEA?

3.2.4. Does the new plant / process design increase the time required for the operator to provide the IAEA with an Interim Inventory List (IIL) after the CoT

3.2.5. Does design increase the expected overall measurement uncertainty of the operator's interim inventory declaration?

3.2.6. If the comparison facility Safeguards Approach included short-notice or no-notice interim inspections, does the design include real time measurement and accounting systems that allow for almost immediate inventory declarations required to support such inspections?

The questions in Table 4 address design differences that would affect the accuracy of inventory change measurements, the timeliness of inventory change reports, and the ability of the IAEA to verify inventory change reports, and other key elements needed to establish and verify material balances capable of detecting diversion.

Table 4 Effect of Design Differences on Inventory Change Measurement

3.3. Does this design impede timely and accurate inventory change (IC) measurements and declarations by the operator and verification by the IAEA?

3.3.1. Does this design reduce the accuracy of or otherwise impede the use of customary Flow Key Measurement Points (FKMP). If so, are there other well defined locations that could be considered by the IAEA as FKMP?

3.3.2. Does the design increase the measurement uncertainties at FKMPs? If so, can the plant accountancy system meet International Target Values (ITV) for inventory changes?

3.3.3. Does the new design impede or preclude IAEA verification of the IC declarations by sample taking, portable or installed measurements systems, or by joint-use of authenticated operator systems?

3.3.4. Does the design impede or preclude IAEA verification of calculated IC declarations such as nuclear material loss and gain?

3.3.5. Does the design impede or preclude IAEA verification of IC declarations that are determined indirectly or based on historical measurement data (e.g., waste transfers to retained waste or measured discards), decrease the accuracy of the determinations, or limit the availability of the historical data.

3.3.6. Does the design increase the time required for the operator to measure, calculate, prepare, and approve the IC declarations?

3.3.7. Does the new design increase the expected overall measurement uncertainty of the operator's inventory change declaration?

The questions in Table 5 address whether the design differences affect the usefulness of other strategic points (safeguards measures not part of the operator's accountability system, such as process monitoring or other instrumentation or containment / surveillance measures) relied upon to provide added assurance to accountability measures for diversion detection or to maintain $\mathrm{CoK}$ of materials or measurements. 
Table 5 Effect of Design Differences on Other Strategic Points

\begin{tabular}{|l|c|}
\hline 3.4. $\begin{array}{l}\text { Does this design impede the introduction of or reduce the usefulness of Other Strategic Points } \\
\text { (OSP) within a Material Balance Area (MBA)? }\end{array}$ & Yes / No \\
\hline 3.4.1. Would OSP be less effective in providing CoK of measured/verified nuclear material (e.g., \\
reduce the effectiveness of surveillance systems or containment devices; make installation \\
of these systems / devices more difficult; impede or preclude access to or maintenance of \\
these systems / devices; make interfaces [e.g., utility support or data transmission ] more \\
difficult)? & Yes / No \\
\hline 3.4.2. Would OSP be less effective in providing additional assurance for high uncertainty \\
verifications done at KMPs (e.g., reduce opportunities for random short-notice sampling by \\
IAEA inspectors; reduce or eliminate opportunities for correlation with measurement data at \\
related locations, reduce the scope or accuracy of Process Monitoring; or limit or preclude \\
IAEA ability to authenticate plant PM systems or introduce independent systems)?
\end{tabular}

\subsection{Resolution of Safeguards Issues}

Use of the FSA screening tool, based upon the comparison of new designs with current, adequately safeguardable comparison designs, can enable designers and their safeguards subject matter experts to identify potential safeguards issues sufficiently early in the design process when there is more design flexibility to resolve them. The issues can be resolved either by making design changes to eliminate or mitigate the issue, or by identifying additional safeguards measures to maintain adequate safeguardability. The FSA screening tool reflected in Table 1can be used to identify the general nature of the issues that need to be addressed and facilitate SRA and designer/operator discussion of the potential safeguards issues with IAEA. At a minimum, by identifying and comparing potential changes in safeguards tools and measures, it should help the designer/operator anticipate how the IAEA might address the issue in its safeguards approach.

The tools for resolving safeguards issues are summarized in Section 4. For example, if the design differences create the potential for a new diversion path, then pathway analysis tools can be employed to identify any unsafeguarded or minimally safeguarded paths and provide insights about the safeguards measures necessary to address the diversion issue. This analysis can identify possible pathways in need of changes in safeguards tools and measures without focusing on technical details. Additional insights may also be obtained from descriptions of safeguards good practices for similar processes, even if they are not necessarily at the same type of facility (e.g., similar processes at the product end of a reprocessing facility and at the feed end of a mixed oxide fuel fabrication facility). The identification of these additional safeguards issues provides information that the designer needs to incorporate design measures to accommodate them, implementing SBD. 


\subsection{Facility Safeguardability Analysis Toolbox}

This section describes a set of tools and techniques that can be used, in combination with the FSA screening tool, presented in Section 3, to support designers in incorporating the concept of Safeguards by Design into the facility design process.

Figure 3 shows the elements of the FSA Toolbox.

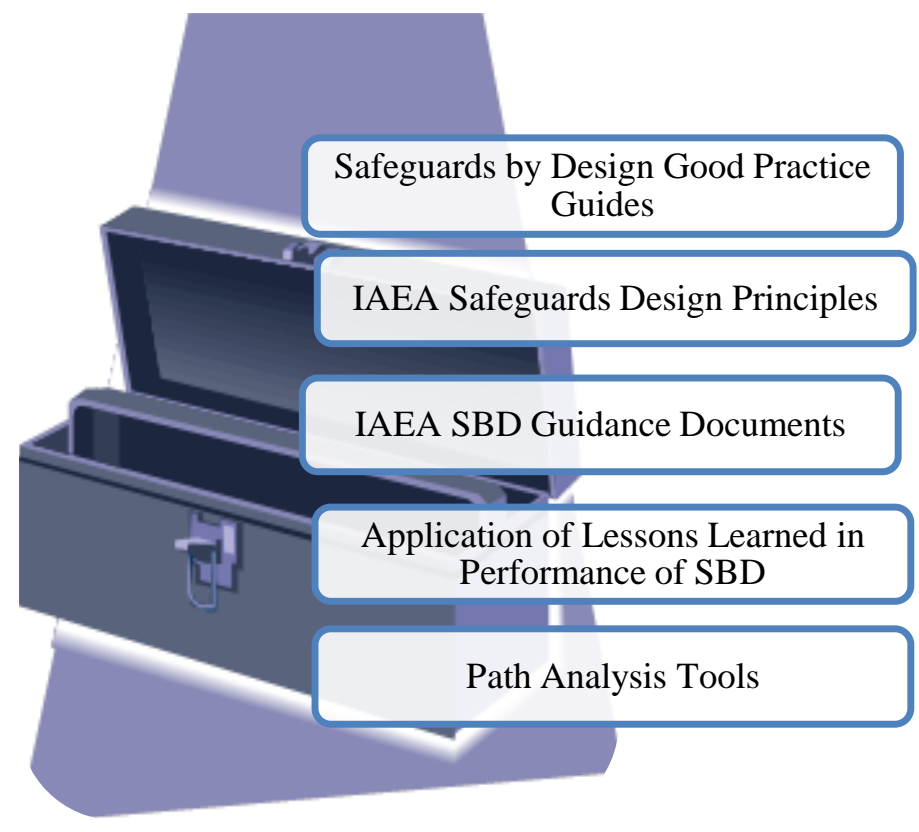

Figure 3 FSA Toolbox Elements

This section introduces these tools and briefly addresses the way a designer could find them of use.

\subsection{SBD Good Practices Guides Developed by the United States}

A hierarchy of requirements exists in the design process, with customer and regulatory requirements at the top and requisite functional requirements that will determine the systems and facility design. The SBD process is intended to develop and implement efficient and cost effective ways to meet these requirements. The National Nuclear Security Administration (NNSA) Next Generation Safeguards Initiative (NGSI) developed the SBD good practice guides described below to provide information that designers will need to accomplish SBD objectives. These documents can be obtained by contacting the NGSI office at (202) 586-0725 and may eventually be available on the internet. 


\subsubsection{Safeguards by Design General Guidance}

Several guidance documents providing generic safeguards requirements and good practices for all types of nuclear facilities have been prepared. They are intended to promote general understanding of the necessity of including safeguards in the facility design process from the earliest stages, and to raise awareness of the expertise necessary to design an effective safeguards system, describe the appropriate timing of the involvement of State and international safeguards authorities, and lists resources available to management and the safeguards design team. These documents include:

- Safeguards by Design General Guidance, LA-UR-09-05802, Rev 1, 2009,

- Implementing the SBD Process, INL/EXT-09-17085, Rev 0, Oct 2009, INL

- Review and Analysis of Development of "Safety by Design" Requirements, PNNL-18848, Oct 2009

\subsubsection{Safeguards Guidance Documents for Nuclear Reactors}

These guidance documents summarize the requirements and good practices for implementing international safeguards for a variety of reactor types:

- NGSI Safeguards by Design Guidance Document Series: High Temperature Gas Reactors using Pebble Fuel

- NGSI Safeguards by Design Guidance Document Series: High Temperature Gas Reactors using Prismatic Fuel

- NGSI Safeguards by Design Guidance Document Series: GEN III/III+ Light Water Reactors

- NGSI Safeguards by Design Guidance Document Series: Research Reactors \& Critical Assemblies

\subsubsection{Safeguards Guidance Documents for Processing and Storage Facilities}

These guidance documents discuss SBD elements for conversion, enrichment, and storage facilities:

- NGSI Safeguards by Design Guidance Document Series: Natural Uranium Conversion Plants

- NGSI Safeguards by Design Guidance Document Series: Enrichment Facilities

- NGSI Safeguards by Design Guidance Document Series: Independent Spent Fuel Storage Installations (ISFSI)

\subsection{IAEA Safeguards Design Documents}

The IAEA has also published several documents that are useful SBD tools for designers. In 1998, a report was published (IAEA, 1998) discussing guidelines for designers of future water cooled power reactors that are intended to minimize the impact of IAEA safeguards on plant operations and ensure efficient and effective acquisition of safeguards data. These guidelines were based on lessons learned in establishing and carrying out safeguards at currently operating nuclear power plants, the ongoing development of safeguards techniques and the feedback of experience from plant operators and designers on the impact of IAEA safeguards on plant operations. The report discussed pathway analyses (including identifying diversion strategies and how to counter them), and compared safeguard approaches for a variety of reactor designs. 
The IAEA also plans to publish a general statement of The Safeguards by Design Process: Principles and High Level Guidelines, in 2012. This will be a general description of the SBD process and its benefits for both IAEA and operators, a set of overarching principles for SBD from the perspective of IAEA, and a discussion of key stakeholder interests with respect to SBD. Following publication of this general statement, IAEA may develop and publish additional detailed safeguards guidance documents for specific facility types; starting with power reactors. (Note: IAEA plans for developing such guides, their organization and scope, and schedules for their publication, are subject to future confirmation by IAEA.) The best way to find out the current status of IAEA SBD guidance is to contact the IAEA directly.

The IAEA documents listed below provide valuable information on safeguards principles that are useful to support SBD. These documents all emphasize that it is important for the IAEA to interact directly and routinely with the R/SRA, the owner/operators, and the designers.

1. Strengthening of Agency Safeguards: The Provision and Use of Design Information, IAEA GOV/2554/Attachment 2/Rev.2/1 April 1992

2. Facility Design and Plant Operation Features that Facilitate the Implementation of IAEA Safeguards SGCP-CCA, STR-360

3. Design Measures to Facilitate Implementation of Safeguards at Future Water Cooled Nuclear Power Plants, TRS-392

4. Nuclear Material Accounting Handbook, IAEA Services Series No. 15, May 2008, IAEA/SG/INF/2

5. Establishment Of IAEA Guidelines For Design Information Examination And Verification, S.J. Johnson, et al. IAEA Safeguards Department

6. IAEA Safeguards: Guidelines for States' Systems of Accounting for and Control of Nuclear Materials, IAEA/SG/INF/2

\subsection{Lessons-learned Reports}

A variety of studies have been performed and papers written concerning lessons learned about effective safeguards implementation during construction of new nuclear energy systems.

Atomic Energy of Canada Limited (AECL) performed a formal SBD study using an approach similar to that proposed in this report to study the effect on safeguards of differences in the ACR-1000 design from older CANDU designs. The approach illustrated the utility of the AECL Design Guide for Safeguards that had been created to guide the design process, and provided useful information to the design team to improve some aspects of the facility design. Finland's SRA, STUK, has published a paper on lessons learned from the Olkiluoto reactor project in which it was discovered during construction that the fuel assemblies and the fuel transfer routes between the fuel building and the new reactor at Olkiluoto were designed in such a way as to complicate continuous surveillance and continuity of knowledge. Earlier identification of this issue in the design requirements would have resulted in easy surveillance of the assemblies in transit without adding any extra cost to plant construction or operation.

A list of reports useful in evaluating SBD lessons learned includes:

- Safeguards-by-Design: The Canadian Experience, IAEA-CN-184/219

- Safeguards by Design - experiences from new nuclear installation - Finland, IAEA-CN-184/24 
PNNL-21698

- Designing and Operating for Safeguards: Lessons Learned From the Rokkasho Reprocessing Plant (RRP), PNNL-19626

- Advanced Safeguards for New Fuel Cycle Facilities - Developments and Recommendations, PNNL-18185

- Application of Safeguards-by-Design to a Reactor Design Process, International Atomic Energy Agency Symposium on International Safeguards, November, 2010, IAEA-CN-184/10

\subsection{Pathway Analysis}

The pathway analysis tools are a set of structured, iterative methods for examining physical paths for material diversion and safeguards coverage of these paths. The pathway analysis methods can be applied at virtually all stages of facility design and construction from conceptual design through commissioning.

The actual methodology to be used to perform the pathway analysis will vary based on the needs of the designers, the facility type, and whether it is a new design or an evolution of an existing design. A variety of tools (Budlong Sylvester, et al 2008, Cojazzi, et al. 2009, GIF/PRPPWG, 2011, Zentner, et.al, 2009) can be used, ranging from detailed modeling of the safeguards systems to more simplistic assessment of the extent to which safeguards measures cover specific paths. The analytical approach should be appropriate for the complexity and severity of the potential safeguard issue. Whatever approach is employed, it is important that the results are structured to provide designers with suitable and appropriate information for resolving safeguards issues in a timely, cost effective fashion.

\subsection{Toolbox Summary}

This toolbox of resources provides the designer and the safeguards subject matter experts on the design team with the information and analytical tools available to resolve the potential safeguards issues identified during the FSA at the earliest stages of design in a manner suitable for discussion with the IAEA. As described above, the toolbox is evolving and more resources will be prepared as lessons are learned in application of SBD. 
PNNL-21698

\subsection{Conclusions}

\subsection{Summary}

The FSA process supports SBD in three areas. It:

1. Describes necessary interactions between the IAEA, the SRA, and the owner / designer of a new or modified facility to determine where SBD efforts can be productively applied,

2. Presents a screening approach intended to identify potential safeguard issues for: a) design changes to existing facilities; b) new facilities similar to existing facilities with safeguards approaches, and c) new designs,

3. Identifies resources (the FSA toolkit), such as good practice guides, design guidance, and safeguardability evaluation methods that can be used by the owner/designer to develop solutions for potential safeguards issues during the interactions with the State regulator and IAEA.

The FSA process presents a structured framework for the application of the SBD tools developed in other efforts. The majority of new facilities are expected to reflect modest design evolution from existing safeguarded facilities (Bjornard, et al. 2009a, 2009b; IAEA, 1998; Wonder \& Hockert, 2011). Therefore, a major focus of the FSA process is efficiently assessing the impact of such an evolution upon required safeguards design features. The more a design evolves, the greater the probability that new safeguards issues will be introduced, the more challenging SBD becomes. For first-of-a-kind facilities or research facilities that involve previously unused processes or technologies, comparison with previously required safeguard design features may not be sufficient. Accordingly, a comprehensive vulnerability or path assessment may be required to adequately identify and assess new safeguards issues. The FSA process is intended to help the designer and its safeguards experts identify early in the design process:

- Areas where elements of previously accepted safeguards approach(es) may be applied to facility modifications or new designs

- Modifications of the design that could mitigate a potential safeguards issue or facilitate a more efficient application of the safeguards approach

- Possible innovative ideas for more efficient application of safeguards

- The potential for changes in elements of the safeguard approach that may be required by IAEA as a result of facility design features and characteristics

These issues may then be presented to the IAEA and the state regulator to be resolved in a timely manner, ensuring that the planned safeguards approach is acceptable and compatible with the facility design at its earliest stages. 
PNNL-21698

\subsection{References}

Bjornard, T., Hebditch, D., Schanfein, M., Bari, R., \& Peterson, P. (2009a) Improving the Safeguardability of Nuclear Facilities, Journal of Nuclear Materials Management, Summer 2009.

Bjornard, T., Bean, R., DeMuth, S., Durst, P., Ehinger, M., Golay, M., Hebditch, D., Hockert, J., and Morgan, J. (2009b) Safeguards-by-Design: Early Integration of Physical Protection and Safeguardability into Design of Nuclear Facilities, Global 2009, Paris, France 2009

Budlong Sylvester, K.W., C.D. Ferguson, E. Garcia, G.D. Jarvinen, J.F. Pilat, and J.W. Tape. (2008) Report of an Elicitation on an Example Sodium Fast Reactor (ESFR) System in Support of the Proliferation Resistance and Physical Protection (PREPP) Working Group. Los Alamos National Laboratory White Paper, Los Alamos, New Mexico, USA.

Cojazzi G.G.M., J. Hassberger, and G. Renda. (2009) “Applying the PR\&PP Methodology for a Qualitative Assessment of a Misuse Scenario in a Notional Generation IV Example Sodium Fast Reactor: Assessing Design Variations." Proceedings of Global 2009, Paris, France, September 6-11, 2009.

Cooper, H., Edwards, T., et al. (2002) Definition of Essential Equipment for Facility Operation - An Operator's Perspective, SRDP-R260 (UK C01093), UK Safeguards Support for the IAEA, London, England March 2002

Ellacott, T., Casterton, J., Kent M. (2010) Safeguards-by-Design: The Canadian Experience, IAEA-CN-184/219, IAEA Vienna, Austria 2010

GIF/PRPPWG/2006/006, (2011) Evaluation Methodology for Proliferation Resistance and Physical Protection of Generation IV Nuclear Energy Systems, Revision 6, September 15, 2011

IAEA, (1972) The Structure and Content of Agreements Between the Agency and States Required in Connection With the Treaty on the Non-Proliferation of Nuclear Weapons, INFCIRC/153 (Corrected). June 1972.

IAEA (1992) Strengthening of Agency Safeguards - The Provision and Use of Design Information, IAEA Board of Governors, GOV/2554/Attachment 2/Rev. 2, Vienna, Austria, 1 April 1992.

IAEA (1996) Strengthening of Agency Safeguards, IAEA Board of Governors, GOV/2863, Vienna, Austria, 6 May 1996.

IAEA (1998) Design Measures to Facilitate Implementation of Safeguards at Future Water Cooled Nuclear Power Plants, TRS392, IAEA, Vienna, Austria. 1998

Johnson, J., Hosoya, M. , Neal, D., and Kikuchi. T (2000) Establishment of IAEA Guidelines for Design Information Examination and Verification, Proceedings of the 21st INMM Annual Meeting, New Orleans, July 2000.

Johnson, S., and Ehinger, (2010) Designing and Operating for Safeguards: Lessons Learned From the Rokkasho Reprocessing Plant (RRP) PNNL-19626, Pacific Northwest National Laboratory, Richland, WA. 2010

Moran, B., Cooley, J., and Pujol, E. Making the IAEA Safeguards System Fully Information Driven (2011) , 35th ESARDA Safeguards Symposium, IAEA, May, 2011.

Wonder, E, and Hockert, J. (2011) Facility Safeguardability Analysis, 33d ESARDA Meeting, Budapest, Hungary, May 2011, PNNL-SA-79588, Pacific Northwest National Laboratory, Richland, Washington., 2011.

Zentner, M.D., G.A. Coles, and I.U. Therios, (2009) “A Qualitative Assessment of Diversion Scenarios for a GEN IV Example Sodium Fast Reactor Using the GEN IV PR\&PP Methodology.” Proceedings of the Global 2009 International Conference on the Nuclear Fuel Cycle, Paris, France, September 6-11, 2009. 


\section{Distribution}

No. of

Copies

\# Name

Organization

Address

City, State and ZIP Code

\# Organization

Address

City, State and ZIP Code

Name

Name

Name

Name

Name (\#

\# Name

Organization

Address

City, State and ZIP Code
No. of

\section{Copies}

\# Foreign Distribution

\# Name

Organization

Address

Address line 2

COUNTRY

\# Local Distribution

Pacific Northwest National Laboratory

Name

Name

Mailstop

Mailstop

Name

Mailstop

Name

Mailstop

Name

(PDF) 


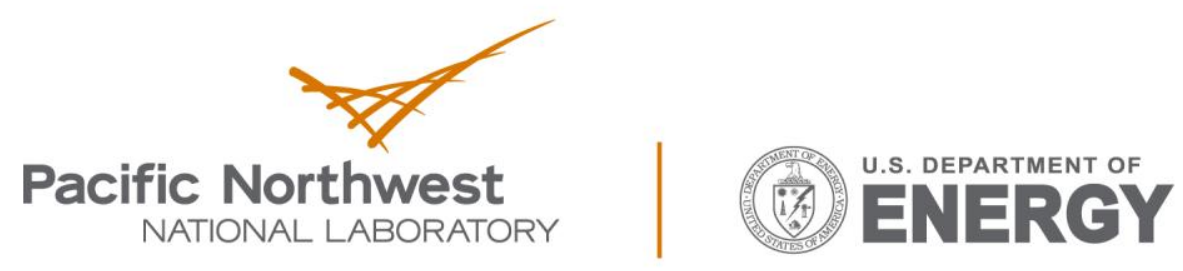

Proudly Operated by Battelle Since 1965

902 Battelle Boulevard

P.O. Box 999

Richland, WA 99352

1-888-375-PNNL (7665)

www.pnnl.gov 